$20 \mid 2012$

Des mobilités aux transports. Regards croisés en Afrique de l'ouest

\title{
Motorbike taxis in the "transport crisis" of West and Central African cities
}

Lourdes Diaz Olvera, Didier Plat, Pascal Pochet et Sahabana Maïdadi

\section{OpenEdition}

Journals

Édition électronique

URL : https://journals.openedition.org/echogeo/13080

DOI : $10.4000 /$ echogeo. 13080

ISSN : 1963-1197

Éditeur

Pôle de recherche pour l'organisation et la diffusion de l'information géographique (CNRS UMR 8586)

Référence électronique

Lourdes Diaz Olvera, Didier Plat, Pascal Pochet et Sahabana Maïdadi, « Motorbike taxis in the "transport crisis" of West and Central African cities », EchoGéo [En ligne], 20 | 2012, mis en ligne le 13 juillet 2012, consulté le 10 août 2021. URL : http://journals.openedition.org/echogeo/13080 ; DOI : https://doi.org/10.4000/echogeo.13080

Ce document a été généré automatiquement le 10 août 2021.

EchoGéo est mis à disposition selon les termes de la licence Creative Commons Attribution - Pas d'Utilisation Commerciale - Pas de Modification 4.0 International (CC BY-NC-ND) 


\title{
Motorbike taxis in the "transport crisis" of West and Central African cities
}

\author{
Lourdes Diaz Olvera, Didier Plat, Pascal Pochet et Sahabana Maïdadi
}

\section{1 - Is public transport still publicly-organized?}

1 Public transport supply in Sub-Saharan cities has undergone a profound change in recent decades as a result of two concomitant processes, namely the disappearance of the large State companies and the overwhelming development of the informal sector with its wide variety of operators. Illegality and clandestine activity may be seen as intrinsic characteristics of the activity of transport micro-businesses in low-income settings (see for example Cervero and Golub, 2007). However, such businesses are often registered with the appropriate authorities and may also comply with some or all of the necessary administrative formalities. More generally, the concept of "informal transport" or "paratransit" is inadequate to express the diversity of organizational forms and production practices exhibited by the myriad of micro-business which constitute this sector (Godard, 2002). We shall nevertheless continue to use them here in view of the lack of a more appropriate universal term for the non-conventional modes of public transport in developing world cities.

2 The changing face of informal transport is indicative of a more general structural crisis that has affected the provision of urban public services since the 1980s. This process of change is still continuing and in many cities, in the last twenty years, the advent of a "new" public transport mode, the "motorbike taxi" has helped to provide more tailormade transport services by reducing the size of vehicles. This development may seem surprising in view of the major urban changes that have accompanied demographic growth: the considerable spatial growth of cities and the continuing importance of central districts which tend to increase daily travel distances and radial flows. In a difficult economic setting, access to the city and its amenities (jobs, education, 
healthcare facilities, markets, social networks, etc.) is essential (Diaz Olvera et al., 2007). Increasingly, such access requires the use of motorized transport. However, the level of household car ownership remains very low in the cities of Sub-Saharan Africa, and the possibility of driving a car is only open to the wealthiest individuals. In some cities, private motorcycles compensate to a very small degree for the shortage of private cars. But, as with cars, shared use of private motorbikes is insufficient to create a massive increase in the number of individuals using the mode (Diaz Olvera et al., 2010).

3 The association of these factors has resulted in an exponential rise in the need for motorized transport that public transport alone can meet. In order to improve the provision of public transport it would seem essential to consolidate transport flows by increasing unit capacities and introducing dedicated bus lanes on the major road network (Sahabana, 2006a) as has be done by the BRT in Lagos which opened in 2008 (Mobereola, 2009). Such developments are still exceptional. In almost all major cities transport supply still relies on paratransit which on its own lacks the political legitimacy, the organizational foundation, and the financial capacity to produce the necessary returns to scale. However, paratransit is genuinely able to innovate and propose a supply of transport to meet demand which, although increasing, is dispersed and barely solvent (Godard, 2002; Carruthers et al., 2005; Diaz Olvera et al., 2008a, 2010).

The rapid development of motorbike taxis is a good example of this capacity for innovation, which involves altering the initial use of a transport mode and its adoption by operators and users. In order to attempt to understand the success of motorbike taxis, in this paper we set out to answer two principal questions. What are the conditions which have made it possible for motorized two-wheelers to become a major public transport mode? What are the roles played by motorbike taxis in daily travel, and more generally in urban systems? The paper is structured in the following way. First, some dimensions of the structural problems of the urban transport sector are presented (Section 2). Then, we highlight the features of the socio-economic and political contexts which have led to the emergence of motorbike taxis in a number of Sub-Saharan Africa cities since the 1980s (Section 3). Section 4 analyzes the levels of mobility among those using motorbike taxis and other modes in Douala and compares them with the situation in Niamey, where motorbikes are used as a personal mode of transport. Last, section 5 considers more broadly the role of motorbike taxis within the urban system as a whole and raises the issue of the conclusions to be drawn concerning the spread of this transport mode, with regard to the interests of the various actors in the transport system and society at large. It also provides suggestions for further research.

5 Statistical analyses presented in this paper are based on quantitative data gathered in household travel surveys undertaken in Douala in 2003 (Sitrass, 2004) and Niamey in 1996 (Diaz Olvera et al., 1999). In Douala, the survey was conducted by Sitrass on behalf of the World Bank for a study aimed at assessing the conditions applicable to mobility and to access to urban services by the poor populations. The survey in Niamey was part of the mobility studies in Sub-Saharan African cities undertaken by the Laboratoire d'Économie des Transports. In both cases, the authors participated in all stages of these studies. Even though the surveys were undertaken at different periods of time and their aims were distinct, the core of the household and individual survey questionnaires was maintained and the same methodology applied (e.g. sampling used a spatial stratification which included distance to city centreand accessibility; 
collection of all trips made by individuals on the day before, whatever the distance and the mode of transport). Thus the common features of both surveys allowed subsequent comparative analyses. The sample sizes are 600 households including 1,885 individuals of 11 years and over in Douala and 757 households including 2,732 individuals of 14 years and over in Niamey.

6 More recent data, or data for Douala and Niamey for the same year, are not available and this shortcoming shows once more evidence of the scarcity of information on daily travel in West and Central African cities. As regards the comparison of data for Douala and Niamey, the seven year gap between the two surveys means that the picture we have is staggered in time and findings must be interpreted as tendencies that are calling for further investigations with more recent data.

\section{2 - Small scale operators or the abdication of the transport authorities}

7 The countries of Sub-Saharan Africa (SSA) are rapidly becoming urbanized and are characterized by the highest rates of urban growth in the world, on average $4.4 \%$ a year in 1990-2005 (World Bank, 2007) and 3.3\% a year in 2005-2010 (UN Habitat, 2008), mainly due to natural growth of the urban population. This rapid demographic growth is accompanied by an increase in the density of central zones and above all the extension of urban areas in zones that lack basic infrastructures and services. The surface area of the cities is thus tending to increase more rapidly than their population, at almost twice the rate in the 1990s in cities with populations of over 100,000 (Angel et al., 2005). The nature of current urban growth is characteristic of cities with poor populations where central government and local authorities lack the resources to manage urban development and to meet the population's growingneeds for services and infrastructure.

8 The situation with regard to urban transport illustrates simultaneously the lack of public and private resources, the disorganization of the supply of public services and the major inequalities with regard to access to these services.

9 The road network is generally underdeveloped and in poor condition, the few asphalt roads that exist are in the centre and on the main routes between the centre and the periphery. The problems that affect roads obviously make the operation of public transport more complex, but they do not explain all the sector's difficulties. In most of the cities state-run transport companies ceased to exist in the 1980's and 1990's due to the combined effect of poor management, the absence of a coherent transport policy and structural adjustment policies. Such policies were based on the declining role of the State from the production of social services and the reduction of public expenditure. Urban transport deregulation, strongly encouraged by Transport Sector Projects, became the rule. Neoliberal policies have played a part in the dismantling of the large public companies, but have not been able to create an equivalent private sector alternative, as has been observed by Sclar and Touber (2011:183) “...the effective outcome of much of the privatization effort [...] is that the policy proved to be capable of facilitating the demise of publicly provided services; but it was rarely able to replace them via an effective market capable of creating equal, let alone better, private sector alternative". The State has, in effect, relinquished its role as a provider of public transport services, but it 
has also ceased to perform its function of supervising transport supply, that is to say, "the act of ensuring that a given good or service is available [which also] involves decisions regarding quantities and qualities, arrangements for production, financing, regulating and enabling producers" (Werna, 1998:16). Consequently, urban transport in African cities is characterized by a "self-regulation by default", as summarized by Kumar and Barrett (2008:33).

Notwithstanding, this policy facilitated the expansion of transport services provided by small registered and unregistered entrepreneurs. The rapid growth of transport supply by these operators has been fostered by a number of factors:

- car ownership is affordable to only a well-off minority of the population,

- strong demand for public transport,

- poor service offered by remaining state-run companies,

- the roads are inadequate or in poor condition, and consequently more suited to small vehicles than tolarge buses,

- the absence of the obligation for the operators to provide services with regulated fares, timetables, routes and service times,

- the complexity of the regulatory framework which is applied very loosely by the authorities. Verifying compliance with regulations usually results in administrative red tape, negotiation and corrupt practices involving the police (Bako-Arifari, 2007; Porter, 2007).

11 Transport supply dominated by small entrepreneurs involves the operation of vehicles of various sizes, from cars to freight vehicles that have undergone more or less rudimentary transformations that enable them to carry passengers. The operators that run the smallest vehicles have an advantage over those with larger vehicles as they are able to use roads that are in poorer condition and find it easier to fill their vehicles. Larger vehicles therefore tend to run on roads that are in better condition and on roads with higher traffic. Vehicles of a wide variety of types often compete on the same route, mainly because the local authorities do not provide overall supervision and coordination of transport supply.

The success of informal transport stems from its ability to adapt to the urban environment, the regulatory framework and the economic conditions by lowering or raising its prices, its ability to change its routes, termini and service points, and its ability to vary its service times. However, the goal of maximizing daily revenue leads operators to concentrate supply on the most profitable links, provide poor quality of service in terms of comfort and safety, and picking up and dropping off passengers outside the designated areas leading to congestion of radial routes during peak periods. Another outcome is the extremely difficult working conditions for bus crews, as exemplified by Rizzo (2011) on Dar es Salaam dala dala ${ }^{1}$ casual wage workers. The activities of informal transport undertakings are often singled out as a major cause of urban malfunction. The limited number of studies that have examined the social costs generated by the way public transport currently operates highlight its contribution to road traffic accidents, congestion and pollution, and the fact that delays and fatigue among bus crews and passengers impair the productivity of urban activities. But the costs the system generates also have important impacts upon the clientele. As fares are not subsidized and the productivity of operators is low (Kumar, Barrett, 2008), as is the income of users, daily travel is a major drain on the budgets of city-dwellers.

13 In the absence of any other alternative to public transport in most major cities and in view of the non-interventionist policies of local authorities, informal operators of 
various sizes running various types of vehicle have become an essential component of urban transportation systems (Lombard, Zouhoula Bi, 2008: 48) in spite of their many shortcomings.

14 It is within this context that an unusual form of public transport has appeared in a number of cities. Motorized two-wheelers, which are traditionally intended for purely private use, have been appropriated for a commercial activity: the motorbike taxi. This form of public transport currently meets a major share of the population's transport needs but elicits a number of criticisms from users, other public transport operators, authorities and the population at large (Mahlstein, 2009).

\section{3 - The increase in motorbike taxi services}

While the urban motorbike taxi is a relative newcomer, its rural ancestor, the bicycle taxi already existed as far back as the 1930s in the Senegalese city of Kaolack (Morice, 1981) and the 1960s in Kenya, Uganda and Benin where it was used to carry both people and goods (Malmberg-Calvo, 1994; Tossou, 1993). Motorbike taxis appeared in Nigeria in the 1970s (Oyesiku, 2001) but their true rise seems to have started in the mid-1980s in Niger, Cameroon, Togo, Benin, Uganda and Kenya ${ }^{2}$ as a development from the bicycle taxi (Agossou, 2004; Howe, Maunder, 2004; Mutiso, Behrens, 2011). While the motorbike taxi is very popular in Uganda and Kenya under the name of boda-boda, its use has above all developed in West and Central Africa under a variety of different local names: zemidjan in Benin and Togo, bendskin in Cameroon, kabu-kabu in Niger, okada or alalok in Nigeria, oleyia in Togo (Agossou, 2004; Guézéré, 2008; Ngabmen et al., 2000; Dille, 2002; Mahlstein, 2009; Oyesiku, 2001; Malmberg-Calvo, 1994; Segbor, 1998).

with other forms of informal transport, the number of motorbike taxis operating in the various cities is unknown and what we have at best are estimates. For example, at the beginning of the 21st century, there would appear to be 50,000 such vehicles in Cotonou (Godard, Ngabmen, 2002) and 70,000 in the whole of Uganda (Howe, Maunder, 2004), 40,000 in Kampala alone (Goodfellow, Titeca, 2012); 22,000 in Douala in 2003 (Sitrass, 2004) and almost 25,000 in 2008 (Breit Consulting, 2008); 66,000 in Lome in 2006 (Guézéré, 2008) and 10,000 in Calabar, Nigeria, in 2008 (Mahlstein, 2009).

The commercial use of motorized two-wheelers can be explained by the combination of three factors: the shortage of urban transport supply, the availability of factors of production and the loose regulatory framework.

\section{1 - The shortage of transport supply}

18 The motorbike taxi is a "bottom-up" response to a shortage of transport affecting private vehicles, road infrastructure and public transport. As the purchase and use of motorized personal vehicles is too expensive due to the population's low income levels, household vehicle ownership rates are extremely low. The majority of the population is thus dependent on public transport for the motorized trips it needs to make. The lack of roads and their poor condition make it difficult for motor vehicles to travel and transport operators are unable to provide the whole urban area with a dense network of services, particularly in unplanned peripheral zones. Moreover, while public transport is very inadequate in major cities, there is usually none at all in smaller ones. 
19 Two types of situations have exacerbated the lack of transport and stimulated the emergence of motorbike taxis. The first of these is the closure of the border between two countries with strong economic and social ties, as was the case between Kenya and Uganda in the early 1970's (Howe, 2003) and between Niger and Nigeria in the mid-1980s (Dille, 2002).The second type of situation involves social tension caused by citizens' demand for democracy, with calls for general strikes as in Lomé, Douala and other cities in Cameroon in the early 1990s (Godard \& Ngabmen, 2002; Ngabmen et al., 2000). Neither public transport nor private vehicles could not go all over town, and motorized two-wheelers took advantage of their unobtrusiveness and handiness to travel off the roads to make up for the lack of transport. ${ }^{3}$

\section{2 - Available factors of production} earners and the unemployed of various ages are able to drive public transport vehicles or do other jobs associated with public transport operation ${ }^{4}$. Even more than in the case of other modes of public transport, being a motorbike taxi driver in Douala 
constitutes a last resort from which $86 \%$ of them earn the majority of their income (Breit Consulting, 2008).

\section{3 - A loose regulatory framework}

The emergence of motorbike taxis was also facilitated by shortcomings in local public transport regulations. When the first motorbike taxis appeared, motorized twowheelers were thought of exclusively as a personal transport mode. In some cases, depending on the characteristics of the vehicle, there was no obligation either to register the vehicle or hold a driving licence. At the time, the administrative and regulatory texts did not even envisage their use for public transport purposes.

The increasing role of motorbike taxis in public transport gradually led the authorities to take more notice of them. Initially, ignorance, indifference and tolerance held sway (Godard and Ngabmen, 2002). In a context where there was a shortage of transport supply, the authorities often tolerated this mode of transport, considering it just as a temporary situation or as a means of reducing the effect of strikes called by the opposition, the "villes mortes" campaigns (Ngabmen et al., 2000; Konings, 2006). Subsequently, the growing number of motorbike taxis has changed the relationship between the different stakeholders in the transport sector. In a short gap of time, motorbike taxis came to be demonized by the general public and the local authorities because of several reasons: their competition with other operators, their power as a pressure group acting on the authorities, other operators and the rest of the population, their aggressive behaviour and driving and the negative externalities (accidents, air pollution, security) they generate.

The local authorities have gradually attempted to control the activities of the motorbike taxis by taking account of them in public transport regulations. There has generally been a considerable disparity between contents of regulations and their application but the situation varies greatly from one country to another or even from one city to another in the same country. In Cameroon, even though the decree that set out the conditions and terms for operating motorbike taxis was issued in November 1995, most operators still do not have the necessary licences and administrative documents and do not comply with other formalities such as the need for the driver and passenger to wear a helmet or the need to paint the vehicle yellow (Sahabana, 2006b). A study of motorbike taxis conducted in 2008 in Douala found that $17 \%$ of the drivers did not hold a driving licence and that $34 \%$ of the vehicles were without registration documents (Breit Consulting, 2008). Even worse, only $73 \%$ of the drivers had at least two of the seven necessary administrative documents, and only $40 \%$ had three.

The ability of motorbike taxi drivers to organize themselves and engage in protests to defend their common interests, as observed in Douala (Konings, 2006), Kampala (Goodfellow, Titeca, 2012) or Cotonou (Godard, Ngagbmen, 2002), may explain why the regulations that apply to them are so lax. In a context of political decentralisation and opening to multipartism, and because of their electoral visibility, their number in the streets, and their central place in daily life of many citizens, motorbike taxis have become a strong political force, as shown by Goodfellow and Titeca (2012) for Kampala. The Kampala City Council, under the opposition party, introduced a tax on the bodaboda taxi licence in 2002, which raised 95 million Ugandan Shillings in 2003. However, 
this measure was soon abandoned in 2004, after the mobilisation of boda-boda drivers and the intervention of the central government. The implementation of other measures failed for the same reasons, as the obligation for boda-boda to operate outside the citycentre in 2009 or to have two helmets, reflective jackets, gloves and a driving permit in 2010 (Goodfellow, Titeca, 2012:268).

In some exceptional cases, application of the regulations soon proved more successful. In Calabar, in Nigeria near the Cameroonian border, the enforcement of regulations started in early 2007. One year later, there was a clear tendency for both the driver and passenger to wear helmets and for the driver to wear a reflective jacket, even though these accessories were not always worn correctly (Mahlstein, 2009).

This brief description of the factors that have led to the existence and development of motorbike taxis reveal close similarities with the other forms of informal public transport that preceded them in Sub-Saharan cities: they appeared as a reaction to shortages in public transport supply and shortcomings in the content and implementation of public transport regulations. Similarities are also apparent in their operating conditions, such as drivers renting the vehicles, the sharing of operating costs between the driver and the vehicle owner and the demanding nature of the work.

The physical characteristics of the motorized two-wheeler are extremely important for its use as a public transport vehicle. The motorbike taxi provides a service which could be described as "minimal": a single passenger without bulky baggage (in theory), but also as a "personalized" door-to-door service, even in areas with poor roads or no roads at all. There is therefore little difference between them and the personal motorized two-wheelers, apart from the systematic presence of at least one passenger and the fact that the journey is paid for. Are there other similarities, in terms of daily travel, between users of private and public vehicles?

\section{4 - Daily travel of users of private and public two- wheelers}

The role of motorbike taxis in daily travel can be assessed by comparing the mobility levels of motorbike taxi users and users of other modes in Douala and the social characteristics of motorbike taxi users from Douala and users of privately-owned twowheelers from Niamey.

\section{1- Motorbike users: an increase in travel}

The classification of individuals according to their use of private or public transport modes on an average weekday (Table 1) shows eight categories, which include individuals who stayed at home all day ("non-travellers"), individuals who made all their trips on foot ("walkers"), users of bendskins (only relevant for Douala, two groups), users of other modes of public transport (one group), users of private motorbikes (two groups) and users of private cars (one group). Motorized two-wheelers in Niamey have the status of a personal vehicle ( $9 \%$ of the population) while in Douala it is clear-cut that their status is that of a public transport mode, the bendskin. While $28 \%$ of the population use a bendskin on a weekday, only $1 \%$ travels on a personal motorbike. 
Motorbike taxis may be used either as the principal mode of transport or for the initial and/or final segments of the trip, in combination with another transport mode, generally public, which carries out the main segment of the trip. This flexibility of motorized two-wheelers means it can replace walking for any segment of the trip and thus improves accessibility and increases the possibilities of using other public transport modes whose routes do not pass near the individual's home, place of work or place of education. Options are increased both in terms of users of public transport and travel. As shown in table 1, in Douala, there are as many bendskin users $(29 \%)$ as there are individuals who exclusively use traditional public transport modes $(28 \%)$, but bendskin users are more mobile.

Table 1 - Travel on a weekday for residents of Niamey and Douala (14 years and over) according to their modal use

\begin{tabular}{|c|c|c|c|c|}
\hline & \multicolumn{2}{|c|}{ Niamey } & \multicolumn{2}{|c|}{ Douala } \\
\hline & $\%$ & $\begin{array}{l}\text { Number } \quad \text { of } \\
\text { trips }\end{array}$ & $\%$ & $\begin{array}{l}\text { Number of } \\
\text { trips }\end{array}$ \\
\hline Non-travellers & 10 & 0 & 8 & 0 \\
\hline Walkers & 53 & 4.4 & 31 & 4.8 \\
\hline Public transport users & 19 & 4.3 & 28 & 4.8 \\
\hline Users of the bendskin solely & - & - & 15 & 5.2 \\
\hline Users of the bendskin and other public transport modes & - & - & 14 & 5.5 \\
\hline Users of private motorbikes & 7 & 6.4 & 1 & 6.7 \\
\hline $\begin{array}{l}\text { Users of private motorbikes and another motorized } \\
\text { mode }\end{array}$ & 2 & 8.0 & - & - \\
\hline Private car users & 9 & 6.3 & 3 & 5.7 \\
\hline Total & 100 & 4.3 & 100 & 4.5 \\
\hline
\end{tabular}

"Walkers consist of individuals who made all their trips on foot during the surveyed day.

The mobility levels of those using private motorized two-wheelers are higher than average. In Niamey, private motorbike users travel as much as car users and those who combine the use of two-wheelers with other motorized modes seem to be hypermobile travellers ( 8 trips per day), but they represent only $2 \%$ of the population. In Douala, a similar situation is observed for motorcyclists, they travel more than all the other categories and make almost 7 trips per day, but they constitute a small sample (1\%). 


\section{2 - Private motorized two-wheelers: a socially distinctive mode of transport in Niamey} the exclusion of all other mechanized modes, and also reduce their walking trips, which account for less than a quarter of all their trips. Related users and deprived users constitute a population which includes more women, which has a lower level of education and includes fewer employed persons than the exclusive users. Their access to a motorized two-wheeler is limited, but it nevertheless allows them to travel more than residents with no access to one at all, e.g. $70 \%$ more than public transport users. They are more frequently passengers on two-wheelers, even though they drive for $40 \%$ (in the case of related users) and $30 \%$ (in the case of deprived users) of their trips. For them, the motorized two-wheeler is a mode they use when the opportunity presents itself, particularly for social trips. In this case, the great majority of the trips made by exclusive users (81\%) are return journeys, while this proportion is slightly lower amongst related users ( $71 \%$ ) and drop amongst deprived users (41\%). Thus, these differentiated configurations in travel patterns reveal the decreasing degree of control over the vehicle between the three groups.

Compared with the private car, use of private motorized two-wheelers among related users and deprived users is considerably lower. This is firstly explained by the capacity of the vehicle, despite the fact that in day-to-day use it frequently carries more than two people at the same time. But the main impediment relates to social constraints which determine whom the driver can carry as a passenger. For instance, travelling with a person of the same sex and the same age group is more acceptable than other alternatives. However, social barriers seem to be less decisive in Douala, where the motorbike taxi has acquired an important role in public transport. 


\section{3 - The bendskin: a public mode of transport for the working poor in Douala}

first difference between private and commercial use of motorized two-wheelers is that women are more dominant than men among bendskin users (54 \%) in Douala. The second feature is that young adults account for an even higher percentage: $69 \%$ of users are between 18 and 34 years old. Incidentally, this feature is also very marked in comparison with other transport users in Douala as this age group only accounts for $42 \%$ of other public transport users, $36 \%$ of walkers and $15 \%$ of motorists.

41 In fact, the bendskin appears to be the motorized mode that is the most used by the poor in Douala, but not bythe poorest. The economically active population accounts for $70 \%$ of users and among those with jobs outside the home, two in five women and a third of the men report using the bendskin to go to work. Motorbike taxis are a transport mode used by a majority of working poor and this is the main feature that distinguishes "public" use of motorized two-wheelers from their private use. This difference is confirmed by two figures: while in Niamey, the "poor" (the population earning less than the median income) account for only $21 \%$ of motorbike users travelling on motorbikes solely ( $30 \%$ otherwise), in Douala, the poor account for $45 \%$ of the motorbike taxi users who use these vehicles in an exclusive manner ( $49 \%$ otherwise), but the poorest quartile of the population is relatively under-represented. The clientele of the bendskins also appears to be poorer than that of "conventional" public transport which "only" has $41 \%$ of poor users. We can put forward two hypotheses to explain this: either there is an economically based decision to prefer bendskins, because they are more affordable than shared taxis, at least for short distances in the city centre and for initial and final segments; or the decision is simply due to a lack of modal choice because of the remoteness of some poor suburbs and the poor condition of the service roads which means that motorbike taxis have little or no competition from other transport operators.

As we have already seen, bendskins may be used either as the principal mode of transport or for the initial and final segments of trips. In the first case, the trips are short, 16 min on average, and made up of 1.5 trip legs. Three-quarters of bendskin trips take place between the individual's home district and a distant district but there are still a significant number of trips to neighbouring districts (more than $20 \%$ ). Two out of five trips are for work purposes, the rest being shared between trips for domestic and social activities. The trips for which the motorbike taxi is used for initial and final segments are longer ( $40 \mathrm{~min}$ on average), more complex (2.8 journeys) and in almost all cases $(98 \%)$ involve trips between the home district and a distant district. These trips are dominated by occupational trips (more than half of them are for work, almost a fifth for education), but more than $20 \%$ of the trips are still made for social reasons.

Motorbike taxis, either alone or combined with other modes, thus provide services that other transport modes, particularly shared taxis, do not: trips or segments that are simultaneously too long to be made on foot as they would be too physically demanding, and too short to represent a profitable market for other public transport modes ${ }^{5}$. Bendskins therefore seem more to complement than to compete with other forms of public transport, both in very dense areas and in the parts of the city where it is difficult to provide four-wheeled transport. They therefore meet needs for transport which are not satisfied by other public transport operators. Nevertheless, motorbike 
taxis are unable on their own to compensate for the accessibility disparities that affect the different residential zones in the city.

\section{5 - Motorbike taxis: who earns what?}

44 ability to satisfy demand for trips that are not covered by other public transport modes, for example short door-to-door trips in city centres or peripheral areas and for access and egress journeys in zones with poor transport services. It is a rapid mode because it avoids the congestion and operating constraints that affect shared taxis and conventional buses, such as the generally fixed nature of routes or the need to wait until the vehicle is full for starting out. In addition to these advantages, they are affordable - four-fifths of users consider the bendskin to be cheap. On average, a motorbike taxi trip costs two-thirds as much as a shared taxi trip (122 CFA Francs and 185 CFA Francs, respectively, at the time of the survey) and is slightly cheaper than a bus journey (150 CFA Francs). Like the other informal transport modes, prices may be negotiated by either the driver or the client and are directly linked to the length of the journey. On average, the price is a third higher when the duration of the journey increases from 5 minutes to over 20 minutes. In terms of cost, therefore, the optimum use of motorbike taxis is for short distance trips.

47 The benefits in terms of mobility are counterbalanced by the dangers of accidents and mugging. They almost unanimously stress the danger of accidents (95\% of respondents) and attacks ( $80 \%$ of respondents), to such an extent that some city 
residents state that they never travel by motorbike taxi and prefer shared taxis or walking. For instance, in Lomé, two thirds of road accidents registered in 2000 involved motorized two wheelers, of which $60 \%$ were motorbike taxis (Guézéré, 2012). The dangers are so great that the population has named hospital casualty departments after the local name of motorbike taxis or the name of the most popular brand of motorcycle (Wamé, 2002, Mahlstein, 2009). In general, as most motorbike taxis operate without insurance and any means of identification, in the event of an accident, users cannot take any action against them.

Like other informal modes of transport (Lombard, 2006), motorbike taxis have provided answers to the shortage of transport supply without the need for investment from the local or national authorities. Their contribution to the daily travel of the population has come to be recognized by the local authorities. Motorbike taxis contribute to more equity in daily travel by widening access to motorized modes to larger population groups, particularly the least underprivileged segment of the urban poor. They improve spatial and temporal accessibility by facilitating access to locations which are problematic for other vehicles, going almost everywhere and stopping near their home. Undoubtedly, due to their role as a connecting link in the intermodal travel chain, motorbike taxis improve local travel and accessibility in the city. Consequently, even more than other modes of public transport, motorbike taxis help to limit the processes of spatial segregation that are at work in the cities of SSA.

While the short-term benefits of motorbike taxis for individuals outweigh their disadvantages, both for users and operators, the assessment for the community in the long term appears to be more mixed. The "dark side" of the motorbike taxi becomes apparent when one looks at the negative externalities that are generated by its growth and its lack of institutional supervision. The large number of motorbike taxis, their impact on congestion, the lack of vehicle maintenance and the poor quality of the fuel used have an adverse impact on combustion processes and pollutant production. In turn, greenhouse gas production increases and air pollution deteriorates the conditions of public health. The health issues are even more apparent when we consider the large number of fatalities and injuries due to road traffic accidents in which motorbike-taxis are involved and public safety issues are also among the externalities generated by the motorbike taxi system. In spite of their lack of internal organization, motorbike taxi drivers form a genuine pressure group that is feared by the general population and even bythe police as they are able to implement aggressive collective action rapidly, for example when authorities conduct checks or in the event of a traffic accident.

Due to the paucity of information, we cannot assert that our findings concerning mobility in motorbike taxis and the related fares or the improvement of access to motorized travel for the underprivileged, particularly the working poor, can be generalized to other cities. Similarly, the viability of the motorbike taxi activity relies heavily on input prices, the affordability of public transport users and the extent of competition amongst motorbike taxi operators and with the other modes of public transport. Rising fuel prices and the increasing importation of cheap Chinese motorbikes, with nevertheless a shorter lifespan, contribute to modify the economic equilibrium of the motorbike taxi activity. Complementary studies on the exhausting working conditions of motor bike-taxi drivers appear quite as essential as the assessment of the environmental impact of the overall mobility systems in African cities. In order to optimize the benefits of the role of motorbike taxis in the urban 
systems and limit collateral impacts, it is necessary to carry out a more precise evaluation of the economical, environmental, social and public health impacts of motorbike taxi activity. This can only be achieved through a comparative research in Sub-Saharan Africa cities where the share of this mode of transport is significant. Such information would provide a sounder basis for local authority supervision and make it possible to achieve better integration between motorbike taxis and the public transport system.

51 The conditions under which urban transport currently operates in many African cities favour small vehicles over larger ones, and generalized competition over complementarity and coordination. A continuation of "laissez-faire" policies appears to be inappropriate both in view of the increasing size of cities and the growing solvency problems facing urban households. It is, however, true that from a short term perspective, the current minimal involvement on the part of the public authorities provides a minimum level of supply for daily mobility needs.

In the longer term, public policies must make a more positive contribution to cities by attempting to bring about socially inclusive, sustainable, urban development. The public authorities currently lack the desire and means to satisfying the travel needs of the urban population a central goal. In response to today's "bottom-up" service provision and in order to obtain the best possible outcome for the community, it is urgent to implement "top-down" regulation that includes all transport modes.

\section{BIBLIOGRAPHIE}

Agossou N. S. A., 2004. Les taxis-motos zemijan à Porto-Novo et Cotonou. Autrepart, 32, p. 135-148.

Angel S., Shepard S., Vivco D., 2005. The dynamics of global urban expansion. Washington D. C., World Bank, Transport and Urban Development Department. http://www.williams.edu/ Economics/UrbanGrowth/WorkingPapers.htm

Bako-Arifari N., 2007. La corruption dans les transports, la douane et les corps de contrôle. In : Blundo G., Olivier de Sardan J.-P. (dir.), Etat et corruption en Afrique : une anthropologie comparative des relations entre fonctionnaires et usagers (Bénin, Niger et Sénégal). Paris, Karthala-APAD, p. 179-224.

Breit Consulting, 2008. Analyse de l'impact de l'augmentation du parc de motocyclettes dans la ville de Douala. Rapport provisoire pour le Ministère des Transports du Cameroun. Programme de politiques de transport en Afrique subsaharienne. Yaoundé, Breit Consulting.

Carruthers R., Dick M., Saurkar A., 2005. Affordability of public transport in developing countries. Washington D. C., The World Bank, Transport Papers n 3, 23 p.

Cervero R., Golub A., 2007. Informal transport: A global perspective, Transport Policy, 14-6, p. 445-457.

Diaz Olvera L., Plat D., Pochet P., Sahabana M., 2010. Entre contraintes et innovations, évolutions de mobilité quotidienne dans les villes d'Afrique subsaharienne. Espace Populations Sociétés, 2-3, p. 337-348. 
Diaz Olvera L., Plat D., Pochet P., 2008a. Household transport expenditure in Sub-Saharan African cities: measurement and analysis. Journal of Transport Geography, 16-1, p. 1-13.

Diaz Olvera L., Plat D., Pochet P., 2008b. Logiques d'usage et formes d'appropriation de la voiture en Afrique subsaharienne. In : Clochard F., Rocci A., Vincent S. (eds), Automobilités et altermobilités. Quels changements? Paris, L'Harmattan, p. 199-211.

Diaz Olvera L., Plat D., Pochet P., 2007. Mobilité quotidienne en temps de crise. Belgeo, 2, p. 173-187.

Diaz Olvera L., Plat D., Pochet P., 1999. Les déplacements quotidiens des Niaméens. Un état des lieux. Lyon, LET, $184 \mathrm{p}$.

Dille B., 2002. K comme Konni ou la mobilité dans une ville moyenne. In :Godard X. (ed.), Les transports et la ville en Afrique au sud du Sahara. Le temps de la débrouille et du désordre inventif. ParisArcueil, Karthala-Inrets, p. 167-180.

Godard X. (ed.), 2002. Les transports et la ville en Afrique au sud du Sahara. Le temps de la débrouille et $d u$ désordre inventif. Paris-Arcueil, Karthala-Inrets, 410 p.

Godard X., Ngabmen, H., 2002. Z comme Zemidjan, ou le succès des taxis motos. In : Godard X. (ed.), Les transports et la ville en Afrique au sud du Sahara. Le temps de la débrouille et du désordre inventif. Paris-Arcueil, Karthala-Inrets, p. 397-406.

Goodfellow T., Titeca K. 2012. Presidential intervention and the changing 'politics of survival' in Kampala's informal economy. Cities, 29-4, p. 264-270.

Guézéré A., 2008. «Oleyia » (taxi-moto) : acteurs et usagers d'un mode de transport artisanal récent à Lomé. Thèse de Doctorat de Géographie, Lomé, Université de Lomé., 455 p.

Guézéré A., 2012 (à paraître). Taxis-motos et insécurité routière dans les villes d'Afrique de l'Ouest, une analyse à partir du cas de Lomé au Togo. Annales de l'Université de Ouagadougou, Presse Universitaires de Ouagadougou.

Howe J., Maunder D. A. C., 2004. Boda boda - lessons from East Africa's growing NMT industry. 10th World Conference on Transport Research, Istanbul, 4-8 July 2004, $10 \mathrm{p}$.

Howe J., 2003. "Filling the middle": Uganda's appropriate transport services. Transport Reviews, 2, p. 161-176.

Konings P. 2006. Solving transportation problems in African cities: Innovative responses by the youth in Douala, Cameroon. Africa Today, 53, p. 35-50.

Kponhassia G., 2003. Reconversions professionnelles, reconversions mentales. La reconversion des salariés ivoiriens au chômage dans le secteur des activités informelles autrefois abandonnées aux 'étrangers'. In : Leimdorfer F., Marie A. (eds), L'Afrique des citadins. Sociétés civiles en chantier (Abidjan, Dakar). Paris, Karthala, p. 343-354.

Kumar A., Barrett F., 2008. Stuck in traffic: Urban transport in Africa. Washington, D. C., The World Bank, AICD, Background Paper, 103 p.

Lombard J., 2006. Enjeux privés dans le transport public d'Abidjan et de Dakar. Géocarrefour, 81-2, p. 167-174.

Lombard J., Zouhoula Bi M.-R., 2008. Minibus et taxis à Abidjan et Dakar : 50 ans de lutte pour la reconnaissance du secteur privé. In : Bredeloup S., Bertoncello B., Lombard J.(éds), Abidjan, Dakar : des villes à vendre ? La privatisation made in Africa des services urbains. Paris, L'Harmattan, p. 43-62. 
Mahlstein M., 2009. Shaping and being shaped. The regulation of commercial motorcycle operation and social change in Calabar, Nigeria. MA Thesis, Basel, Univ. of Basel, Institute of Social Anthropology, $123 \mathrm{p}$.

Malmberg-Calvo C., 1994. Case study on intermediate means of transport. Bicycles and rural women in Uganda. Washington, D.C., World Bank, SSATP Working Paper $n^{\circ} 12 . \mathrm{http}: / /$ www4.worldbank.org/afr/ssatp/Resources/SSATP-WorkingPapers/SSATPWP12.pdf

Mobereola D., 2009. Premier bus à haut niveau de service en Afrique. Le "BRT-Lite" de Lagos. Washington, D. C., Banque Mondiale, Document d'analyse SSATP ${ }^{\circ} 9$, série transport urbain, http://siteresources.worldbank.org/EXTAFRSUBSAHTRA/Resources/DP09-Lagos-BRT_fr.pdf

Morice A., 1981. Les vélos de Kaolack. Cahiers d'Etudes Africaines, 81-83, p. 197-210. www.persee.fr Mutiso W., Behrens R., 2011. Boda boda bicycle taxis and their role in urban transport systems: Case studies of Nakuru and Kisumu, Kenya. $30^{\text {th }}$ Southern African Transport Conference: Africa on the Move, Pretoria, $15 \mathrm{p}$.

Ngabmen H., Habyarimana M., Eboumbou Jemba C., 2000. Etude exploratoire sur les taxis-motos dans les villes africaines. Les "bend skin" de Douala. Rapport pour le Ministère français des Affaires Etrangères. Groupe Interdisciplinaire d'Etudes et de Recherche sur les Transports (Giret).

Oyesiku K. O., 2001. City poverty and emerging mobility crisis: The use of motorcycle as public transport in Nigerian cities. $9^{\text {th }}$ World Conference of Transport Research, Seoul, 22-27 July, 16 p.

Porter G., 2007. Transport planning in sub-Saharan Africa. Progress in Development Studies, 7-3, p. 251-257.

Rizzo M., 2011. The struggles of informal transport workers in Tanzania: Debunking the myth of micro solutions. Development Viewpoint, $n^{\circ} 68$, Nov., 2 p. http://www.soas.ac.uk/cdpr/ publications/dv/dv68.html

Sahabana M., 2006a. Les autobus en site propre intégral, une solution à la crise des transports dans les grandes agglomérations subsahariennes. Thèse pour le Doctorat de Sciences Economiques, mention Economie des Transports, Lyon, Université Lyon 2.

Sahabana M., 2006b. Les motos-taxis à Douala et leur perception par les pouvoirs publics : entre tolérance d'un secteur pourvoyeur d'emplois et de transport et volonté d'éradiquer une activité incontrôlable. Secondes rencontres internationales CIDEGEF/Ville management "Evolutions institutionnelles et gouvernance dans le système de transports en Afrique Sub-Saharienne", Douala, 20-24 Nov., $15 \mathrm{p}$.

Sclar E., Touber J., 2011. Economic fall-out of failing urban transport systems: an institutional analysis. In: Dimitriou H. T., Gakenheimer R. (Eds), Urban transport in the developing world. A handbook of policy and practice. Cheltenham (UK), Edward Elgar, p. 174-202.

Segbor P. K., 1998. Quels transports urbains à Lomé en l'an 2000 ? In: Codatu (ed), Urban transport policy. A sustainable development tool. Rotterdam, Balkema, p. 827-830.

Sitrass, 2004. Poverty and urban mobility in Douala. Final Report, SSATP Report No 09/04/Dla, Washingtion, D.C., World Bank, 143 p. http://www4.worldbank.org/afr/ssatp/Resources/ PapersNotes/Douala_en.pdf

Teurnier P., Mandon-Adoléhoume B., 1994. L'intégration du transport artisanal dans un service public de transport urbain : le cas de Dakar. Paris, Inrets-Codatu.

Tossou C. A., 1993. Les taxi-motos urbains de Cotonou : sécurité et environnement. In : Actes de la Codatu Transport urbain dans les pays en développement, Tunis, 15-19 Fév. 1993, p. 45-55. 
UN Habitat, 2008. State of the world's cities 2010/2011 - Cities for all: Bridging the urban divide.Nairobi, United Nations, $244 \mathrm{p}$.

Wamé B., 2002. Les moto-taxis ou la danse de la mort. http://www.afrik.com/article4754.html

Werna E., 1998. Urban management, the provision of public services and intra-urban differentials in Nairobi. Habitat International, 22-1, p. 15-26.

World Bank, 2007. World Development Indicators, World Bank, Washington D.C. http://

siteresources.worldbank.org/DATASTATISTICS/Resources/table3_10.pdf

\section{NOTES}

1. Dala dala is the local name for privately owned mini- and midibuses.

2. In towns such as Kisumu and Nakuru, bicycle boda-boda still assures substantial modal share of short trips but suffers from the increasing motorbike taxi operations (Mutiso, Behrens, 2011).

3. A similar situation was observed in Mexico City in August 2006. When the political party that had lost the presidential election blocked vehicular traffic in the downtown area, paid transport by private motorbike appeared spontaneously within the affected area.

4. The literature contains many examples in Sub-Saharan Africa such as, for example, the "maîtrisards" in Dakar, who are shared-taxi operators with university degrees, described by Teurnier, Mandon-Adoléhoumé (1994) and the case of an accountant in Abidjan who became a woro woro driver, reported by Kponhassia (2003).

5. On weekdays, the average duration of a shared taxi trip is $26 \mathrm{~min}$ (10 min more than the average duration of a bendskin trip), in particular because of the need to make access journeys on foot.

\section{RÉSUMÉS}

Dans nombre de villes d'Afrique subsaharienne, un mode original de transport commercial de personnes, le moto-taxi, connaît un développement spectaculaire. L'objectif de cet article est d'analyser les conditions qui ont rendu possible l'émergence des motos-taxis comme l'un des principaux modes collectifs, et d'éclairer le rôle qu'ils tiennent dans la mobilité urbaine. L'essor des motos-taxis peut s'expliquer par le manque d'offre de transport public, par la disponibilité des facteurs de production, par le laxisme de la régulation publique en matière de transport urbain. Les résultats de deux enquêtes ménages mobilité menées en Afrique centrale (Douala) et de l'Ouest (Niamey) montrent que, là où ils sont utilisés, les motos-taxis peuvent contribuer à élargir l'accès à la mobilité motorisée et à satisfaire des besoins de mobilité non pris en compte par d'autres modes de transport collectif.

Motorized two-wheelers have been appropriated for a commercial activity, the motorbike taxi, in a number of Sub-Saharan African cities. The aim of this paper is to determine the conditions which have made it possible for motorized two-wheelers to become a major public transport mode, and to highlight their role in daily travel. The rise of motorbike taxis can be explained by the shortage of transport supply, the availability of factors of production and the permissiveness 
of the regulatory framework. Motorbike taxis extend access to motorized modes of transport to larger groups of population whose travel needs are not satisfied by the other modes of public transport.

\section{INDEX}

Mots-clés : mobilité quotidienne, moto-taxi, offre de transport public, pauvreté, transport urbain

Keywords : motorbike taxi, poverty, public transport supply, travel behaviour, urban transport Thèmes : Sur le Champ - Sur le Terrain

\section{AUTEURS}

\section{LOURDES DIAZ OLVERA}

Lourdes Diaz Olvera, lourdes.diaz-olvera@entpe.fr, est chargée de recherche du MEDDTL au Laboratoire d'Economie des Transports (Université de Lyon-Ecole Nationale des Travaux Publics de l'Etat, CNRS UMR 5593).

\section{DIDIER PLAT}

Didier Plat, didier.plat@entpe.fr, est enseignant chercheur au Laboratoire d'Economie des Transports (Université de Lyon-Ecole Nationale des Travaux Publics de l'Etat, CNRS UMR 5593).

\section{PASCAL POCHET}

Pascal Pochet, pascal.pochet@entpe.fr, est chargée de recherche du MEDDTL au Laboratoire d'Economie des Transports (Université de Lyon-Ecole Nationale des Travaux Publics de l'Etat, CNRS UMR 5593)

\section{SAHABANA MAIIDADI}

Sahabana Maïdadi, sahabana@yahoo.fr, était chargée de mission à la Communauté Urbaine de Douala (au moment de la réalisation de ce travail).

Ils ont publié récemment :

- Diaz Olvera L., Plat D., Pochet P., 2011. Se déplacer pour se soigner. Pratiques et obstacles à Conakry et Douala. Cahiers de Géographie du Québec, Vol. 55, n¹56, "Géographie de la santé", p. 555-573.

- Diaz Olvera L., Plat D., Pochet P., Sahabana M., 2010. Entre contraintes et innovations, évolutions de mobilité quotidienne dans les villes d'Afrique subsaharienne. Espace Populations Sociétés, $\mathrm{n}^{\circ} 2-3$, "Nouvelles mobilités dans les Suds", p. 337-348.

- Diaz Olvera L., Plat D., Pochet P., 2010. A l'écart de l'école ? Pauvreté, accessibilité et scolarisation à Conakry. Revue Tiers Monde, n²02, p. 167-183. 